\title{
A COMPREHENSIVE CHEMICAL CHARACTERIZATION OF IN SITU OPHTHALMIC GEL
}

\author{
INSAN SUNAN KURNIAWANSYAH ${ }^{1 *}$, IYAN SOPYAN², TAOFIK RUSDIANA ${ }^{1}$, FIRDA SILVIA PRAMASHELA ${ }^{3}$, ANAS \\ SUBARNAS 4
}

1Department of Pharmaceutics and Pharmaceutical Technology, Faculty of Pharmacy, Universitas Padjadjaran, Sumedang, West Java, Indonesia, ${ }^{2}$ PUSDI Drug Delivery and Drug Disposition Faculty of Pharmacy, Universitas Padjadjaran, Sumedang, West Java, Indonesia, ${ }^{3}$ Faculty of Pharmacy, Universitas Padjadjaran, Sumedang, West Java, Indonesia, ${ }^{4}$ Department of Pharmacology and Clinical Pharmacy, Faculty of Pharmacy, Universitas Padjadjaran, Sumedang, West Java, Indonesia *Email: insan.sunan.kurniawansyah@unpad.ac.id

Received: 17 Jun 2021, Revised and Accepted: 03 Sep 2021

\section{ABSTRACT}

In situ ophthalmic gel is a gel preparation that is initially in the form of ophthalmic solution that dripped into the eye and then the solution turns into a gel after contact with the surface of the eye. In situ gel will undergo phase change to gel due to pH, electrolyte and temperature conditions. So that the preparation of ophthalmic in situ gel is required characterization to make sure that the prepared preparations meet the standards and are safe when used. Chemical evaluation includes $\mathrm{pH}$, concentration, chemical bonds, crystallization and drug and polymer interactions. The purpose of this review is to discuss the evaluation methods used in preparations, and to see whether the $\mathrm{pH}$ of in situ ophthalmic gel formulation that provided can met the ideal pH requirements of the eye, so that the ophthalmic in situ gel preparation would not causing irritation and liquid tear production.

Keywords: Chemical characteristics, In situ gel, Ophthalmic, Irritation

(C) 2021 The Authors. Published by Innovare Academic Sciences Pvt Ltd. This is an open access article under the CC BY license (https://creativecommons.org/licenses/by/4.0/] DOI: https://dx.doi.org/10.22159/ijap.2021v13i6.42457. Journal homepage: https://innovareacademics.in/journals/index.php/ijap

\section{INTRODUCTION}

One of the most process limitations in eye delivery is approve and the retention of optimum drug concentrations at work sites within the eye. Ophthalmic dose forms, like solutions, ointments, gels, and compound inserts have supported the efforts to increase the ocular duration of the drug for topical application to the eye [1].

An unchanged gel could be a clear compound resolution that liquid in storage, however reborn to elastic gel that is insert into the attention because of the transition section of the compound. The advantages given by the gel increase in ocular duration and area unit bioavailable; enable delivery of doses which will be reproduced befittingly and increase patient delivery. This conversion happen as result of the compound incorporated within the system will modified because of changes in temperature, $\mathrm{pH}$ or solution composition of the liquid lacrimal $[1,2]$.

The gel forming system in situ provides the advantage of straightforward administration and prolonged retention on the surface of the attention, thus overcoming the disadvantages of standard dose forms, which might improve patient safety and increase ocular improvement, which might improve treatments and aspect effects [3, 4].

The ideal ophthalmic drug delivery should be able to maintain drug unleash and to stay round the eyes for long delivery [5].

The completion-to-gel activity will occur because:

a. Physical stimulus: these embrace changes in temperature, electrical fields, and light.

b. Chemical stimuli: enable changes in $\mathrm{pH}$ and activated ions from biological fluids.

c. Organic chemistry stimuli: these embrace changes in atomic number 20 levels $[6,7]$.

The gel will divided into 3 varieties supported their section change: sensitive to temperature, sensitive to $\mathrm{pH}$, and sensitive to strength. Temperature-sensitive materials largely embrace block copolymers and poloxamer [8]. $\mathrm{pH}$ sensitive materials embrace cellulose ester and carboxylic acid polymers, which, by dynamic the pH worth of the setting, will accessed via section [9].
Gels in places that area unit sensitive to a larger $\mathrm{pH}$ use carbohydrates and alternative additional acidic polymers, and their low $\mathrm{pH}$ will cause irritation to the surface of the attention [10].

The formation of gels elsewhere created supported physiological stimulation shaped by gels created with changes in $\mathrm{pH}$. During this system, the model resolution triggered by a amendment in $\mathrm{pH}$. At $\mathrm{pH}$ 4.4 the formulation could be a flow resolution that will increase the action $\mathrm{pH}$ is raised by tear fluid to $\mathrm{pH} 7.4$. The $\mathrm{pH}$ changes around 2.8 units once step by step from the $\mathrm{pH} 4.4$ formulation into the tear film resulting in a really speedy transformation from liquid latex to thick gel. Nucleon in response to changes in environmental pH. Polymers with giant amounts of ionising teams referred to as polyelectrolytes. Swelling of the colloidal gel will increase the compilation of $\mathrm{pH}$ on the far side increasing the weak (anionic) acid cluster. Medicine developed in liquid solutions have many limitations as well as bioavailability and alignments to distill by tear fluid. To approve these factors and exploit the delivery of this drug by creating poly (acrylic acid) (PAA) resolution thaat can gel at $\mathrm{pH} 7.4$ we have a tendency to found that at high concentrations it causes gelation on the surface of the attention before being neutral by lacrimal fluid. This drawback is solve largely by transferring PAA with consistency enhancing compound HPMCs that turn out a $\mathrm{pH}$ responsive compound mixture containing an answer at $\mathrm{pH}$ four and a gel at $\mathrm{pH} 7.4$ [11].

\section{Method}

Article review contains a review of several published articles. The process of finding sources from this review article in May 2020 carried out through Pubmed using the keyword "Chemical characterization of In situ ophthalmic gel". The search for keywords in detail is as follows: "In situ ophthalmic gel [All Sectors] AND" Chemical chaeracterization "[All Fields] AND "Evaluation" [All Fields] AND "Drugs" [All Fields] by sorting [Year of Publication] in the last $5 \mathrm{y}$, and NOT "Reviewing articles". From 50 journals after sorted by inclusion and exclusion criteria, 30 journal references used in this journal review.

\section{Chemical characterization}

The chemical characterization of a preparation needs to known in order to guarantee that a drug or preparation meets the requirements and can used safely. Chemical characteristics include: crystallization, concentration, $\mathrm{pH}$, drug interactions with polymers, and others related to other chemical bonds. 


\section{RESULTS AND DISCUSSION}

Table 1: Chemical characterization of In situ ophthalmic gel preparations in the past 5 y

\begin{tabular}{|c|c|c|c|c|c|}
\hline No & $\begin{array}{l}\text { Active } \\
\text { substance }\end{array}$ & Method & $\begin{array}{l}\text { Evaluation of } \\
\text { chemical }\end{array}$ & Chemical evaluation results & References \\
\hline 1. & $\begin{array}{l}\text { Ketorolac } \\
\text { Tromethamine }\end{array}$ & $\begin{array}{l}\text { HPLC, Differential Scanning } \\
\text { Calorimetry (DSC), FTIR }\end{array}$ & $\begin{array}{l}\mathrm{pH} \text { and } \\
\text { concentration }\end{array}$ & $\begin{array}{l}\text { The } \mathrm{pH} \text { is neutral, ranging from } 6.43 \pm 0.1 \text { to } \\
7.06 \pm 0.01 \text { and the concentration of } \mathrm{P} 407 \\
\text { increases in concentration } \\
\text { P407: } \mathrm{P} 188(23: 10 \mathrm{w} / \mathrm{v} \%) \text { and }(23: 15 \mathrm{w} / \mathrm{v} \%)\end{array}$ & [13] \\
\hline 2. & Ciprofloxacin & HPLC, FTIR & $\mathrm{pH}$ & 7 & {$[14]$} \\
\hline 3. & Vancomycin & $\begin{array}{l}\text { UV Spectroscopy, Differential } \\
\text { Scanning Calorimetry (DSC), } \\
\text { FTIR }\end{array}$ & $\mathrm{pH}$ & $4.8-5$ & [15] \\
\hline 4. & $\begin{array}{l}\text { Levofloxacin } \\
\text { Hemihydrate }\end{array}$ & UV Spectroscopy, FTIR & $\mathrm{pH}$ & $7.05-7.24$ & [16] \\
\hline 5. & Brinzolamide & HPLC & $\mathrm{pH}$ & $6.06-6.54$ & [17] \\
\hline 6. & $\begin{array}{l}\text { Betaxolol } \\
\text { hydrochloride }\end{array}$ & HPLC & $\begin{array}{l}\text { Concentration dan } \\
\mathrm{pH}\end{array}$ & $\begin{array}{l}\text { Concentration poloxamer } 407(\mathrm{P} 407)(22 \% \\
(\mathrm{b} / \mathrm{v})) \\
\text { and poloxamer } 188(\mathrm{P} 188)(3.5 \%(\mathrm{~b} / \mathrm{v})) \text { and } \\
\mathrm{pH}=6.51-6.52\end{array}$ & [18] \\
\hline 7. & Celecoxib & HPLC, UV Spectroscopy & $\mathrm{pH}$ & $7.6-7.8$ & [19] \\
\hline 8. & Ketoconazole & $\begin{array}{l}\text { HPLC, Differential Scanning } \\
\text { Calorimetry (DSC), FTIR, XPRD }\end{array}$ & $\begin{array}{l}\text { Crystallization, } \\
\text { interactions } \\
\text { between drugs and } \\
\text { polymers, pH }\end{array}$ & $\begin{array}{l}\text { amorphous form and there is no interaction } \\
\text { between the drug and its polymer, } \mathrm{pH}=7.4\end{array}$ & {$[20]$} \\
\hline 9. & Itraconazole & Spectrophotometry & $\mathrm{pH}$ & $6.60-6.84$ & {$[21]$} \\
\hline 10. & Moxifloxacin & UV Spectroscopy and FTIR & $\mathrm{pH}$ & $6.5-6.9$ & [22] \\
\hline 11. & Acyclovir & HPLC & $\mathrm{pH}$ & 7 & [23] \\
\hline 12. & $\begin{array}{l}\text { Triamcinolone } \\
\text { Acetonide }\end{array}$ & $\begin{array}{l}\text { HPLC, Differential Scanning } \\
\text { Calorimetry (DSC), FTIR }\end{array}$ & $\mathrm{pH}$ & $6.8 \pm 0.5$ & {$[24]$} \\
\hline 13. & Cefuroxime & $\begin{array}{l}\text { HPLC, Differential Scanning } \\
\text { Calorimetry (DSC) }\end{array}$ & $\mathrm{pH}$ & 7.2 & {$[25]$} \\
\hline 14. & $\begin{array}{l}\text { Tobramycin } \\
\text { Sulfate }\end{array}$ & $\begin{array}{l}\text { HPLC, FTIR, Differential } \\
\text { Scanning Calorimetry (DSC) }\end{array}$ & $\begin{array}{l}\mathrm{pH}, \mathrm{pKa}, \\
\text { concentration }\end{array}$ & $\begin{array}{l}\mathrm{pH}=4.5-5 \\
\mathrm{pKa}=6.5 \\
\text { Concentration }=1.25-1.5 \% \mathrm{~b} / \mathrm{v}\end{array}$ & {$[26]$} \\
\hline 15. & Ganciclovir & $\begin{array}{l}\text { HPLC, Differential Scanning } \\
\text { Calorimetry (DSC) }\end{array}$ & $\mathrm{pH}$ & 7.4 & {$[27]$} \\
\hline 16. & $\begin{array}{l}\text { Azelastine } \\
\text { Hydrochloride }\end{array}$ & $\begin{array}{l}\text { UV Spectroscopy, Differential } \\
\text { scanning calorimetry (DSC) }\end{array}$ & $\mathrm{pH}$ & $6.9-7.1$ & {$[28]$} \\
\hline 17. & Levofloxacin & $\begin{array}{l}\text { UV Spectroscopy, Differential } \\
\text { Scanning Calorimetry (DSC) }\end{array}$ & $\mathrm{pH}$ & $4.7-7.4$ & [29] \\
\hline 18. & Nepafenac & HPLC & $\mathrm{pH}$ & $5.62-5.73$ & {$[30]$} \\
\hline 19. & Voriconazole & UV and FTIR Spectroscopy & $\mathrm{pH}$ & $4.9-7.1$ & {$[31]$} \\
\hline 20. & Dexamethasone & $\begin{array}{l}\text { HPLC, Differential Scanning } \\
\text { Calorimetry (DSC), and FTIR }\end{array}$ & $\mathrm{pH}$ & $6.56 \pm 0.15$ & {$[32]$} \\
\hline 21. & $\begin{array}{l}\text { Brimonidine } \\
\text { tartrate }\end{array}$ & reversed-phase HPLC & $\mathrm{pH}$ & 7 & [33] \\
\hline 22. & Ketotifen & HPLC & $\mathrm{pH}$ & $6-8$ & {$[34]$} \\
\hline 23. & $\begin{array}{l}\text { Brinzolamide } \\
\text { Dimethyl } \\
\text { Sulfoxide }\end{array}$ & $\begin{array}{l}\text { FTIR and Raman } \\
\text { Spectroscopy,UV Spectroscopy }\end{array}$ & $\mathrm{pH}$ & $6.8-7.2$ & [35] \\
\hline 24. & Bimatoprost & $\begin{array}{l}\text { HPLC, Differential Scanning } \\
\text { Calorimetry (DSC), FTIR }\end{array}$ & $\mathrm{pH}$ & 7.2 & [36] \\
\hline 25. & Besifloxacin & HPLC, UV Vis Spectroscopy & $\mathrm{pH}$ & $4.7-5.2$ & [37] \\
\hline 26. & $\begin{array}{l}\text { Dorzolamide } \\
\text { Hydrochloride }\end{array}$ & UV Spectroscopy & $\mathrm{pH}$ & $5.16 \pm 0.01$ & [38] \\
\hline 27. & $\begin{array}{l}\text { Ciprofloxacin } \\
\text { Hydrochloride }\end{array}$ & Spectrophotometry and FTIR & $\mathrm{pH}$ & $6.49-6.58$ & [39] \\
\hline 28. & Tetrahydrozoline & HPLC, FTIR & $\mathrm{pH}$ & $6.8-7.4$ & {$[40]$} \\
\hline 29. & Acetazolamide & UV Vis Spectrophotometry & $\mathrm{pH}$ & $5.4-5.7$ & [41] \\
\hline 30. & Loteprednol & HPLC & $\mathrm{pH}$ & $7.40-7.55$ & [42] \\
\hline
\end{tabular}

\section{Evaluation method of drug content}

HPLC

HPLC method is the method most widely used to characterize a preparation, one of which is evaluation of drug content. Active substances that use the HPLC method, namely Ketorolac tromethamine, Ciprofloxacin, Levofloxacin Hemihydrate, Brinzolamide, Betaxolol Hydrochloride, Celecoxib, Ketoconazole, Acyclovir, Triamcinolone Acetonide, Cefuroxime, Tobramycin
Sulfate, Ganciclovir, Nepafenac, Dexamethasone, Ketotifen, Bimatoprost, Besifloxacin, Tetrahydrozoline, Lotedprenol and Brimonidine tartrate used reversed-phase HPLC method.

Determination of drug content was done by dissolving $0.125 \mathrm{ml}$ of gel in situ in a $25 \mathrm{ml}$ mobile phase. The HPLC analysis followed by an estimated percentage of the drug [12]

Examples of procedures for evaluating drug content using the HPLC method: 


\section{Brinzolamide}

A total of $1 \mathrm{ml}$ of the formulation was dissolved in $100 \mathrm{ml}$ phosphate buffer $(\mathrm{pH}=7.4)$ before using HPLC to determine drug concentration. BLZ concentrations determined by HPLC. Separation carried out at $30^{\circ} \mathrm{C}$ using a reverse phase $\mathrm{C} 18$ column $(5 \mu \mathrm{m}, 4.6$ $250 \mathrm{~mm}$ ). The mobile phase consist of methanol and water $600: 40$, $\mathrm{v} / \mathrm{v}$ ). The detection wavelength was $257 \mathrm{~nm}$, and a flow rate of 1.0 $\mathrm{ml} / \mathrm{min}$ was used.

\section{Ganciclovir}

High performance liquid chromatography system (Waters 600 pumps, Waters, Milford, MA), equipped with fluorescence detectors (HP1100, Hewlett Packard, Waldbronn, Germany) and reverse phase C8 columns ( $4 \mathrm{~mm}, 250 \mathrm{~mm} 4.6 \mathrm{~mm}$, Phenomenex, Torrance, CA) was used for analysis. The detector used at $16 \mathrm{pmt}$, at excitation and emission wavelengths of 265 and $380 \mathrm{~nm}$, respectively. The mobile phase consists of a mixture of $15 \mathrm{mmol}$ phosphate buffer ( $\mathrm{pH} 2.5)$ and acetonitrile $2.5 \%$ pumped at a flow rate of $1 \mathrm{ml} / \mathrm{min}$.

\section{Nepafenac}

Photodiode Array Detector use to measure nepafenac in formulation, release, permeation, and tissue retention studies. Kinetex C18 reverse phase HPLC column $(5 \mathrm{~mm}$ particles, $150 \mathrm{~mm}$ $4.6 \mathrm{~mm}$ ) used for nepafenac analysis. The mobile phase consists of 40:60 acetonitrile: water; the flow rate is set at $1 \mathrm{ml} / \mathrm{min}$. The absorbance wavelength is set at $254 \mathrm{~nm}$, with an injection volume of $10 \mathrm{ml}$.

\section{Brimonidin tartrate}

The reverse phase HPLC method was developed and validated for brimonidine tartrate analysis. HPLC (Shimadzu LC-20 AD) equipped with a photodiode array detector (PDA), rheodyne injector with a 20 $\mu \mathrm{l}$ loop and C18 column (chromasil, $250 \mathrm{~mm} \times 4.6 \mathrm{~mm}$, $\$ \mathrm{~mm}$ particle size) were used. Optimized separation was achieved using a mobile phase consisting of a buffer of citric acid monohydrate $\mathrm{pH} 3$, methanol and water (30:20:50) at $1.0 \mathrm{ml} / \mathrm{min}$ and the flow rate was detected at $246 \mathrm{~nm}$.

\section{UV-VIS spectrophotometry}

The method used in the evaluation of drug content that is most widely used after HPLC is UV-Vis Spectrophotometry. In this review the active substance uses the UV-Vis Spectrophotometry method is Vancomycin, Levofloxacin Hemihydrate, Itraconazole, Moxifloxacin, Azelastine $\mathrm{HCl}$, Levofloxacin, Voriconazole, Brinzolamide Dimethyl Sulfoxide, Dorzolamide Hydrochloride, Ciprofloxacin Hydrochloride, and Acetazolamide.

Examples of procedures for evaluating drug content with the UV-Vis Spectrophotometry method:

\section{Levofloxacin}

Spectrophotometric method (Variant Cary 60) developed using pure water as a solvent system. For the formulation test analysis, an accurate amount of weighing in situ gel solution $(1 \mathrm{ml})$ is equivalent to $15 \mathrm{mg}$ of levofloxacin transferred into a $100 \mathrm{ml}$ volumetric flask, and the volume adjusted to pure water. The prepared sample solution is dilute by transferring $3 \mathrm{ml}$ of the solution in a $100 \mathrm{ml}$ volumetric flask, and the volume was adjusted using purified water. The drug content of the prepared sample solution measured by a UV spectrophotometer at $289 \mathrm{~nm}$. The method validated for linearity, precision, specificity, and resistance testing.

\section{Azelastine $\mathrm{HCl}$}

For drug content, the weighed amount $(100 \mathrm{mg})$ of Azelastine $\mathrm{HCl}$ loaded with ocular polymer in situ gel formulations was diluted using $5 \mathrm{ml}$ of methanol. The dispersion produced by vortex uses Vortex shaker (Hicon ${ }^{\circledR}$, New Delhi, India) and shaken for $10 \mathrm{~min}$.

\section{Besifloxacin}

The drug content determined by diluting $1 \mathrm{ml}$ of the inifloxacin in situ gel formulation with $10 \mathrm{ml}$ with the newly simulated tear fluid having a $\mathrm{pH}$ of 7.4. BSF concentrations were determined use to UV-
Visible spectrophotometer at $290 \mathrm{~nm}$ (Shimadzu 1700, Japan) using simulated tear fluid as a blank.

\section{Evaluation method of drug-polymer interactions FT/IR}

FTIR method is the method most widely used to characterize a preparation, one of which is evaluation of drug-polymer interactions. Active substances that use the FTIR method is Ketorolac tromethamine, Ciprofloxacin, Vancomycin, Levofloxacin Hemihydrate, Ketoconazole, Moxifloxacin, Triamcinolone Acetonide, Tobramycin Sulfate, Voriconazole, Dexamethasone, Brinzolamide Dimethyl Sulfoxide, Bimatoprost, Ciprofloxacin Hydrochloride, Tetrahydrozoline.

Examples of procedures for evaluating drug-polymer interactions with the FTIR method:

\section{Ciprofoloxacin}

Fourier transforms infrared spectroscopy the chemical structure of a blank and loaded poly CIP (NIPAAM-MAA-VP) was studied by Fourier infrared spectroscopy (FTIR) transformation. FTIR spectra were obtained at $4 \mathrm{~cm} 1$ resolution with a minimum scan of 256 per spectrum. All measurements carried out at room temperature. The spectrum of water, $\mathrm{CO} 2$ and $\mathrm{KBr}$ were reduced from the spectrum of the sample and the procedure is carried out under nitrogen gas to prevent interference with humidity.

\section{Tetrahydrozoline}

ATR FT-IR Spectrometry used to examine the spectrum of polymers, drugs, and formulations of blanks and ideal drugs, to show that the substances are compatible with each other. The spectrum analyzed at spectral resolution of $4 \mathrm{~cm}-1$ in the frequency range of 4,000-400 $\mathrm{cm}-1$ using the ATR-FTIR Spectrometer (Perkin Elmer, Spectrum 100 FT-IR Spectrometer). The peak position was determined using Perkin Elmer Spectrum Version 6.0.2 Software.

\section{Differential scanning calorimetry (DSC)}

The method used in the evaluation of drug-polymer interactions that is widely used is Differential Scanning Calorimetry (DSC). In this review the active substances using the Differential Scanning Calorimetry (DSC) method is Ketorolac Tromethamine, Vancomycin, Ketoconazole, Triamcinolone Acetonide, Cefuroxime, Tobramycin Sulfate, Ganciclovir, Azelastine Hydrochloride, Levofloxacin, Dexamethasone, Bimatoprost.

Examples of procedures for evaluating drug-polymer interactions with the DSC method:

\section{Ketorolac tromethamine}

The DSC study conducted at Mettler Toledo DSC 822e0, Switzerland. Medicines, polymers (P407 and P188) as well as their physical mixture (PM) with KT were weight separately in an aluminum pan, covered with an aluminum lid and tightly sealed using a pan press (Thermal Science, USA). Once on the calorimeter, the temperature of the pan gradually rises from $25^{\circ} \mathrm{C}$ to $300^{\circ} \mathrm{C}$ at a speed of $10^{\circ} \mathrm{C} / \mathrm{min}$. Nitrogen is clean at a flow rate of $45 \mathrm{ml} / \mathrm{min}$.

\section{Triamcinolone acetonide}

Differential scanning calorimeters (DSC 25, TA instruments, New Castle, DE, USA) are used to observe the fusion and recrystallization behavior of drugs with excipients. Samples for DSC analyze include TA and the physical mixture of the lipid phase (in the same ratio as for the formulation) were melted and compacted. Estimate. $5 \mathrm{mg}$ of sample, each sealed in an aluminum pan, placed on the sample platform. Reference pan, aluminum pan sealed empty, placed on the reference platform. The pan is heat from 25 to $32^{\circ} \mathrm{C}$ at a rate of $20^{\circ} \mathrm{C} / \mathrm{min}$ under a nitrogen purifier $(20 \mathrm{ml} / \mathrm{min})$.

\section{Levofloxacin}

The thermal behavior of levofloxacin, physical mixture of levofloxacin and polymers and lyophilized preparations studied by differential scanning calorimetry (DSC) using Perkin Elmer 7 DSC (Waltham, MA). Samples were analyze by scanning at $4-40{ }^{\circ} \mathrm{C}$ at a rate of $5{ }^{\circ} \mathrm{C} / \mathrm{min}$ in a nitrogen gas environment $(20 \mathrm{ml} / \mathrm{min})$. 


\section{XPRD}

The XPRD method used in the ketoconazole formulation. The crystalline state of the NPs of the prepared drug compared to that of the pure ketoconazole powder was studied using XRPD (D/max 2500; Rigaku, Tokyo, Japan). The diffraction patterns of the samples recorded at a scan speed of 0.5000 degree $/ \mathrm{min}$.

\section{pH determination method}

The method of checking pH with a device called a pH meter. Each formulation examined by dispersing $2.5 \mathrm{~g}$ of the formulation in 25 $\mathrm{ml}$ of pure water. The $\mathrm{pH}$ meter must calibrated before use with buffer solutions at $\mathrm{pH} 4$ and 7 [13]

However, the discussion this time explains more about the $\mathrm{pH}$ of a preparation. Because every piece of literature is list, all the formulations characterize the $\mathrm{pH}$ of the preparation

Chemical characteristics of some active substances in situ gel ophthalmic preparations over the past $5 \mathrm{y}$ :

\section{Ketorolac tromethamine}

The resulting preparations are clear and transparent both in a liquid and gel state. Concentration of P407 increased concentration of P407: P188 $(23: 10 \mathrm{w} / \mathrm{v} \%)$ and $(23: 15 \mathrm{w} / \mathrm{v} \%)$ the $\mathrm{pH}$ of the P407/P188 $n$ situ gel formulation was measured using a precalibrated $\mathrm{pH}$-meter. All formulations found to have a neutral $\mathrm{pH}$, ranging from $6.43 \pm 0.1$ to $7.06 \pm 0.011$ [13].

\section{Ciprofloxacin}

Ciprofloxacin (NIPAAm-MAA-VP) poly nanoformulation used as an eye delivery system represents both temperature and gelation properties that are triggered by in situ $\mathrm{pH}$. PNIPAAm (thermosensitive polymer) combined with MAA (pH-sensitive polymer) was used as a gelling agent. The formulation developed is a clear solution, which converted into a gel at temperatures above $36^{\circ} \mathrm{C}$ and $\mathrm{pH} 7$ [14].

\section{Vancomycin}

The $\mathrm{pH}$ of the in situ gel forming system ranges from 4.8 to 5.1 for all formulations, which are suitable for ophthalmic applications [15].

\section{Levofloxacin hemihydrate}

Gellan-based processed compositions prepared in situ ophthalmic solution forming levofloxacin gel. All formulations designed found to have test, $\mathrm{pH}$, and osmolality in an acceptable range. For the $\mathrm{pH}$ test it produces a range of 7.5-7.24 which is within the acceptable range [16].

\section{Brinzolamide}

For each batch formulated, the $\mathrm{pH}$ value was measured using a $\mathrm{pH}$ meter that was previously calibrated using a standard buffer of $\mathrm{pH}=$ 4.0 and $\mathrm{pH}=7.0$ according to established procedures. The $\mathrm{pH}$ value of solution in situ gel found to range between 6.06 and 6.54 for all formulations [17].

\section{Betaxolol hydrochloride}

Concentration formulations of P407 and P188 are set to 22\% (w/v) and $3.5 \%$. Formulations containing $22 \%(\mathrm{w} / \mathrm{v}) \mathrm{P} 407$ and $3.5 \%$ $(\mathrm{w} / \mathrm{v}) \mathrm{P} 188$ meet the requirements. The $\mathrm{pH}$ value of the gel solution in situ was found to be between 6.51-6.52 for all formulations [18].

\section{Celecoxib}

Initial $\mathrm{pH}$ values for Celecoxib formulations were in the range of 7.67.8. After $6 \mathrm{mo}$, there was little or no change in the $\mathrm{pH}$ value of the formulations stored at $30{ }^{\circ} \mathrm{C}$ and $35{ }^{\circ} \mathrm{C}$, because their $\mathrm{pH}$ values maintained in the range $6.8-7.8$ at $30^{\circ} \mathrm{C}$ and $6.4-7.8$ at $35^{\circ} \mathrm{C}$. This $\mathrm{pH}$ value was still in the range $\mathrm{pH}$ that easily tolerated by natural buffering of the eye system without irritation or discomfort [19].

\section{Ketoconazole}

No peak drug characteristics observed in the formulations that contained NP PLGA drugs, which is evidence that there were no crystalline medicinal ingredients in optimized drug formulations. This is an indication of changes in drug crystallinity and homogeneous drug dispersion in the PLGA matrix. The results of ketoconazole crystallization are amorphous and there is no interaction between the drug and its polymer and $\mathrm{pH} 7.4$ for all formulations [20].

\section{Itraconazole}

The $\mathrm{pH}$ of all formulations before gelation that found towards acidic side (2.8 $\pm 0.50-3.20 \pm 0.40)$ and after gelation, it shifted to $6.60 \pm 0.15$ $6.84 \pm 0.34$. This explains the ability of the sol-to-gel transition in eye instilation. In addition, formulations with a $\mathrm{pH}$ range of 6.8-7.4 considered safe and acceptable for ocular delivery [21].

\section{Moxifloxacin}

Gel formed in situ shows the release of the drug with a $\mathrm{pH}$ free time for more than $10 \mathrm{~h}$ due to the presence of nanoparticles containing moxifloxacin. $\mathrm{pH}$ is between 6.5-6.9 for all Moxifloxacin formulations [22].

\section{Acyclovir}

In situ gel matrix formulations based on KC and HPMC were carried out in $500 \mathrm{ml}$ of simulated tears prepared at $\mathrm{pH} 7.0$ using the dialysis method [23].

\section{Triamcinolone acetonide}

The $\mathrm{pH}$ of the Triamcinolone formulation is $6.8 \pm 0.5$, which is close to the $\mathrm{pH}$ of the lacrimal liquid. Therefore, Triamnicolone with $0.3 \%$ (F13) of gellan gum was considered optimal and used for further learning [24].

\section{Cefuroxime}

A weighted PF127 (14\% w/v) was added to E1 to obtain M-TNH. SLN-based nanocomposite thermosensitive (S-TNH) hydrogels were prepared as follows: SLN made from E2 by the method reported above; after precipitation, a weighted amount of PF127 (20\% w/v) added to the SLN aqueous dispersion to obtain S-NTH. In both cases, 7.2 was the $\mathrm{pH}$ produced [25].

\section{Tobramycin sulfate}

The level of chitosan protonation basically depends on $\mathrm{pH}$, because it is a weak polycationic polymer with $\mathrm{pKa} 6.5$. The $\mathrm{pH}$ of the TPP 5.0 solution and the chitosan solution between 4.5 and 5.0 with an increase in chitosan concentration from 0.5 to $1.5 \% \mathrm{w} / \mathrm{v}$ [26].

\section{Ganciclovir}

$\mathrm{pH}$ of the preparation $=7.4$ on the ganciclovir preparation produced [27].

\section{Azelastine HCl}

The $\mathrm{pH}$ of Azelastine Hydrochloride the previous formulations gelated more towards the acid side $(3.20 \pm 0.60$ to $3.80 \pm 0.30)$ and after the gelation shifted to $6.90 \pm 0.11$ to $7.1 \pm 0.54$. Explain that the ability of the sol to transition gel in ocular gradually. In addition, formulations in the pH range of 6.8 to 7.4 considered safe and acceptable for eye delivery [28].

\section{Levofloxacin}

The selected gel in situ prepared turns out to be clear and light yellow in color. The formulation remains in a liquid state at $\mathrm{pH} 4.7$ but is immediately convert into a gel at $\mathrm{pH} 7.4$, when applied to the eye [29].

\section{Nepafenac}

The $\mathrm{pH}$ of the nepafenac formulation is $5.73,5.62,5.63$, respectively. $\mathrm{pH}$ is still safe and can accepted by the eyes [30].

\section{Voriconazole}

The Voriconazole in situ gel formulation formulation characterized, which showed a pH of 4.9-7.1 that was still eligible [31]. 


\section{Dexamethasone}

The Voriconazole in situ formulation gel formulation was characterized, which showed a $\mathrm{pH}$ of $6.56 \pm 0.15$ which was still eligible [32].

\section{Brimonidine tartrate}

All formulations found to be transparent above $\mathrm{pH} 7$ (physiological conditions). The $\mathrm{pH}$ of the formulation adjusted to $4.0 \pm 0.1$ with the addition of a $0.5 \mathrm{M}$ sodium hydroxide solution. The $\mathrm{pH}$ of the therapeutic agent applied to the eye can vary from 3.5 to 8.527. The capacity of gel formation observed in tear fluid. Gel capacity indicates that the formulation will get the gel under physiological conditions [33].

\section{Ketotifen}

The $\mathrm{pH}$ of the formulation is between 6.0 and 8.0 which indicates the Ketotifen formulation meets the requirements [34].

\section{Brinzolamide dimethyl sulfoxide}

In the aqueous phase, thromethamine (Tris buffer) add to pure water and the $\mathrm{pH}$ is adjusted between 6.8 and 7.2 using $1 \mathrm{M}$ orthophosphoric acid using an Orion Star A211 pH meter, India [35].

\section{Bimatoprost}

The $\mathrm{pH}$ of the Bimatoprost formulation is 7.2 which indicates the Bimatoprost formulation meets the requirements [36].

\section{Besifloxacin}

Besifloxacin formulations is liquid at room temperature with a $\mathrm{pH}$ range of 4.7-5.2 and were converted to a gel phase at $\mathrm{pH} 7.4$, that is, tears with isotonic for physiological (tear) tears [37].

\section{Dorzolamide hydrochloride}

The Dorzolamide $\mathrm{HCl}$ formulation has a $\mathrm{pH}$ value of $5.16 \pm 0.01$. $\mathrm{pH}$ is an important parameter in the reception and tolerance of the formulation by the eye. The tear $\mathrm{pH}$ is around 7.4 with a buffering capacity that tolerates a $\mathrm{pH}$ of around 4-8. $\mathrm{pH}$ values outside this range, due to stimulate flashing and tearing, reduce the bioavailability of the drug. In this study, all formulations were prepared using phosphate buffer $\mathrm{pH} 5.8$ as a solvent. It should noted that DRZ has a pH of 4-6 that is the highest stability [38].

\section{Ciprofloxacin hydrochloride}

The $\mathrm{pH}$ of the gel solution in situ found to be around 6.49-6.58 for all formulations. The IG3 formulation has a $\mathrm{pH}$ of 6.53 which is an acceptable range for eye preparation [39].

\section{Tetrahydrozoline}

The $\mathrm{pH}$ of the Tetrahydrozoline formulation produces a range 6.87 to 7.4. After $3 \mathrm{mo}$, the stability of the gel in situ was re-evaluated resulting in successive $\mathrm{pH}$ of $6.76 ; 6.98 ; 7.1$ [40].

\section{Acetazolamide}

The $\mathrm{pH}$ value of the prepared AZA NE is in the range of 5.4 to 5.7. Therefore, it is sufficient for their application to the eye because the NE prepared is not buffer and can adjusted to physiological values with tears. The value obtained is also able to maintain the stability of the drug, because AZA is very unstable at the base $\mathrm{pH}$ value and has a $\mathrm{pH}$ value of 4-5 at maximum stability [41].

\section{Loteprednol}

The ophthalmic dosage form must be clear enough and the $\mathrm{pH}$ must be close to the $\mathrm{pH}$ of the tear. All NE-ISG (NE-ISG1-NEISG5) formulations are clear and transparent with $\mathrm{pH}$ in the range 7.407.55 that meets the standards and is safe [42].

\section{pH of In situ ophthalmic gel preparations}

One of the most significant parameters is the $\mathrm{pH}$ of the ocular formulation. Eye $\mathrm{pH}$ must be maintained at normal levels (4-8), because a change from acidic to alkaline $\mathrm{pH}$ can cause eye injury [43,
44]. Thus, the ocular formulation that has just been prepared should not change the neutral ocular $\mathrm{pH}$ [45]. The $\mathrm{pH}$ recorded from the gel in situ meets requirements can be assumed that the gel in situ will not cause irritation and immediate tear fluid production [46].

Tears have an average $\mathrm{pH}$ of 7.4 and do not have a strong buffering system. Therefore, the $\mathrm{pH}$ of the eye drops given will determine the eye's current $\mathrm{pH}$. If the eye drops are acidic, they can cause the formation of insoluble complexes from denatured proteins. Strong alkaline eye drops will also damage the eye cell membrane integrity. Therefore, the ideal eye drug must have a pH between 6.8 and 7.4 [47].

However, $\mathrm{pH}$ values from 3.5 to 8.5 can be tolerated if they are not made or only very little buffered because in this case the buffer capacity of the tears is able to adjust the $\mathrm{pH}$ physiologically to the administrative level $[48,49]$.

$\mathrm{pH}$ affects the solubility and stability of the drug in an ophthalmic formulation. It must be such that the formulation will remain stable at that $\mathrm{pH}$. The $\mathrm{pH}$ of the in situ gel system prepared after addition of all ingredients will measure using a pH meter [50].

\section{CONCLUSION}

In situ ophthalmic gel is a gel preparation that is initially in the form of ophthalmic solution that dripped into the eye and then the solution turns into a gel after contact with the surface of the eye. Evaluation methods in making in situ gel are drug content evaluations using HPLC and UV-Vis Spectroscopy methods. Then the method of evaluating drug-polymer interactions such as FTIR, DSC, and XPRD. The results of testing the $\mathrm{pH}$ of the preparations in this literature are still relatively safe and meet the ideal $\mathrm{pH}$ standard of eye fluid, 4-8. However, in general formulas the average dosage of normal dosage is 7.4 as in accordance with the $\mathrm{pH}$ of the tear fluid.

\section{FUNDING}

Nil

\section{AUTHORS CONTRIBUTIONS}

All authors have contributed equally.

\section{CONFLICTS OF INTERESTS}

Declared none

\section{REFERENCES}

1. Nanjawade BK, Manvi FV, Manjappa AS. In situ-forming hydrogels for sustained ophthalmic drug delivery. J Controlled Release. 2007;122(2):119-34. doi: 10.1016/j.jconrel. 2007.07.009, PMID 17719120.

2. Ludwig A. The use of mucoadhesive polymers in ocular drug delivery. Adv Drug Delivery Rev. 2005;57(11):1595-639. doi: 10.1016/j.addr.2005.07.005, PMID 16198021.

3. Cholkar K, Patel SP, Vadlapudi AD, Mitra AK. Novel strategies for anterior segment ocular drug delivery. J Ocul Pharmacol Ther. 2013;29(2):106-23. doi: 10.1089/jop.2012.0200, PMID 23215539.

4. Kumar K, Dhawan N, Sharma H, Vaidya S, Vaidya B. Bioadhesive polymers: novel tool for drug delivery. Artif Cells Nanomed Biotechnol. 2014;42(4):274-83. doi: 10.3109/21691401.2013.815194, PMID 23859698.

5. Sathali AH, Mohanambal E, Arun K. Formulation and evaluation of $\mathrm{pH}$ triggered in situ gelling system of levofloxacin. Indian J Pharm Educ Res. 2011;45:58-64.

6. Nagalakshmi S, Seshank RR, Shanmuganathan S. Formulation and evaluation of stimuli sensitive $\mathrm{pH}$ triggered in-situ gelling system of fluconazole in ocular drug delivery. Int J Pharm Sci Res. 2014;5:1339-44.

7. Nanjawade BK, Manjappa AS, Murthy RS, Pol YD. A novel pH triggered in situ gel for sustained ophthalmic delivery of ketorolac. Asian J Pharm Sci. 2009;4:189-99.

8. Matanovic MR, Kristl J, Grabnar PA. Thermoresponsive polymers: insights into decisive hydrogel characteristics, mechanisms of gelation, and promising biomedical applications. Int J Pharm. 2014;472(1-2):262-75. doi: 10.1016/j.ijpharm.2014.06.029, PMID 24950367. 
9. Singh NK, Lee DS. In situ gelling $\mathrm{pH}$ - and temperature-sensitive biodegradable block copolymer hydrogels for drug delivery. J Controlled Release. 2014;193:214-27. doi: 10.1016/ j.jconrel.2014.04.056, PMID 24815421.

10. Patel A, Cholkar K, Agrahari V, Mitra AK. Ocular drug delivery systems: an overview. World J Pharmacol. 2013;2(2):47-64. doi: 10.5497/wjp.v2.i2.47, PMID 25590022.

11. Lajri G, Ravindranath $\mathrm{S}$. Ophthalmic $\mathrm{pH}$ sensitive in-situ gel: a review. J Drug Delivery Ther. 2019;9:682-9.

12. Mandal S, Thimmasetty MK, Prabhushankar G, Geetha M. Formulation and evaluation of an in situ gel-forming ophthalmic formulation of moxifloxacin hydrochloride. Int J Pharm Investig. 2012;2(2):78-82. doi: 10.4103/2230973X.100042, PMID 23119236.

13. MA Fathalla Z, Vangala A, Longman M, Khaled KA, Hussein AK, El-Garhy OH, Alany RG. Poloxamer-based thermoresponsive ketorolac tromethamine in situ gel preparations: design, characterisation, toxicity and transcorneal permeation studies. Eur J Pharm Biopharm. 2017;114:119-34. doi: 10.1016/j.ejpb.2017.01.008, PMID 28126392.

14. Davaran S, Lotfipour F, Sedghipour N, Sedghipour MR, Alimohammadi S, Salehi R. Preparation and in vivo evaluation of in situ gel system as dual thermo-/pH-responsive nanocarriers for sustained ocular drug delivery. J Microencapsul. 2015;32(5):511-9. doi: 10.3109/ 02652048.2015.1065915, PMID 26190215.

15. Allam A, El-Mokhtar MA, Elsabahy M. Vancomycin-loaded niosomes integrated within $\mathrm{pH}$-sensitive in-situ forming gel for treatment of ocular infections while minimizing drug irritation. J Pharm Pharmacol. 2019;71(8):1209-21. doi: 10.1111/jphp.13106, PMID 31124593.

16. Bhalerao H, Koteshwara KB, Chandran S. Levofloxacin hemihydrate in situ Gelling ophthalmic Solution: formulation Optimization and in vitro and in vivo Evaluation. AAPS PharmSciTech. 2019;20(7):272. doi: 10.1208/s12249-0191489-6, PMID 31372767.

17. Sun J, Zhou Z. A novel ocular delivery of brinzolamide based on gellan gum: in vitro and in vivo evaluation. Drug Des Devel Ther. 2018;12:383-9. doi: 10.2147/DDDT.S153405, PMID 29503531.

18. Huang W, Zhang N, Hua H, Liu T, Tang Y, Fu L, Yang Y, Ma X, Zhao Y. Preparation, pharmacokinetics and pharmacodynamics of ophthalmic thermosensitive in situ hydrogel of betaxolol hydrochloride. Biomed Pharmacother. 2016;83:107-13. doi: 10.1016/j.biopha.2016.06.024, PMID 27470557.

19. Ibrahim MM, Abd-Elgawad AH, Soliman OAE, Jablonski MM. Stability and ocular pharmacokinetics of celecoxib-loaded nanoparticles topical ophthalmic formulations. J Pharm Sci. 2016;105(12):3691-701. doi: 10.1016/j.xphs.2016.09.019, PMID 27789031.

20. Ahmed TA, Aljaeid BM. A potential in situ gel formulation loaded with novel fabricated poly(Lactide-co-glycolide) nanoparticles for enhancing and sustaining the ophthalmic delivery of ketoconazole. Int J Nanomed. 2017;12:1863-75. doi: 10.2147/IJN.S131850, PMID 28331311.

21. Jaiswal M, Kumar M, Pathak K. Zero order delivery of itraconazole via polymeric micelles incorporated in situ ocular gel for the management of fungal keratitis. Colloids Surf B Biointerfaces. 2015;130:23-30. 10.1016/j.colsurfb.2015.03.059, PMID 25889081.

22. Kesarla R, Tank T, Vora PA, Shah T, Parmar S, Omri A Preparation and evaluation of nanoparticles loaded ophthalmic in situ gel. Drug Delivery. 2016;23(7):2363-70. doi: 10.3109/10717544.2014.987333, PMID 25579467.

23. Li P, Wang S, Chen H, Zhang S, Yu S, Li Y, Cui M, Pan W, Yang X. A novel ion-activated in situ gelling ophthalmic delivery system based on $\kappa$-carrageenan for acyclovir. Drug Dev Ind Pharm. 2018;44(5):829-36. doi: 10.1080/03639045.2017.1414232, PMID 29212376.

24. Tatke A, Dudhipala N, Janga KY, Balguri SP, Avula B, Jablonski MM. In situ gel of triamcinolone acetonide-loaded solid lipid nanoparticles for improved topical ocular delivery: Tear kinetics and ocular disposition studies. Nanomaterials. 2019;9:1-17.
25. Sapino S, Peira E, Chirio D, Chindamo G, Guglielmo S, OliaroBosso S, Barbero R, Vercelli C, Re G, Brunella V, Riedo C, Fea AM, Gallarate M. Thermosensitive nanocomposite hydrogels for intravitreal delivery of cefuroxime. Nanomaterials (Basel). 2019;9(10). doi: 10.3390/nano9101461, PMID 31618969.

26. Khan S, Warade S, Singhavi DJ. Improvement in ocular bioavailability and prolonged delivery of tobramycin sulfate following topical ophthalmic administration of drug-loaded mucoadhesive microparticles incorporated in thermosensitive in situ gel. J Ocul Pharmacol Ther. 2018;34(3):287-97. doi: 10.1089/jop.2017.0079, PMID 29211593.

27. Yang $X$, Shah SJ, Wang Z, Agrahari V, Pal D, Mitra AK. Nanoparticle-based topical ophthalmic formulation for sustained release of stereoisomeric dipeptide prodrugs of ganciclovir. Drug Delivery. 2016;23(7):2399-409. doi: 10.3109/10717544.2014.996833, PMID 25564964.

28. Devi S, Saini V, Kumar M, Bhatt S, Gupta S, Deep A. A novel approach of drug localization through development of polymeric micellar system containing azelastine $\mathrm{HCl}$ for ocular delivery. Pharm Nanotechnol. 2019;7(4):314-27. doi: $10.2174 / 2211738507666190726162000$, PMID 31362666.

29. Jain P, Jaiswal CP, Mirza MA, Anwer MK, Iqbal Z. Preparation of levofloxacin loaded in situ gel for sustained ocular delivery: in vitro and ex vivo evaluations. Drug Dev Ind Pharm. 2020;46(1):50-6. doi: 10.1080/03639045.2019.1698598, PMID 31818154

30. Shelley H, Rodriguez Galarza RM, Duran SH, Abarca EM, Babu RJ. In situ gel formulation for enhanced ocular delivery of nepafenac. J Pharm Sci. 2018;107(12):3089-97. doi: 10.1016/j.xphs.2018.08.013, PMID 30170009.

31. Pandurangan DK, Bodagala P, Palanirajan VK, Govindaraj S Formulation and evaluation of voriconazole ophthalmic solid lipid nanoparticles in situ gel. Int J Pharm Investig. 2016;6(1):56-256-62. doi: 10.4103/2230-973X.176488, PMID 27014620.

32. Wen Y, Ban J, Mo Z, Zhang Y, An P, Liu L, Xie Q, Du Y, Xie B, Zhan X, Tan L, Chen Y, Lu ZYi feng wen, et al. A potential nanoparticleloaded in situ gel for enhanced and sustained ophthalmic delivery of dexamethasone. Nanotechnology. 2018;29(42):425101:425101. doi: 10.1088/1361-6528/aad7da.

33. Barse RK, Tagalpallewar AA, Kokare CR, Sharma JP, Sharma PK Formulation and ex vivo-in vivo evaluation of $\mathrm{pH}$-triggered brimonidine tartrate in situ gel for the glaucoma treatment using application of 32 factorial design. Drug Dev Ind Pharm. 2018;44(5):800-7. doi: 10.1080/03639045.2017.1414229, PMID 29228819.

34. Zhu L, Ao J, Li P. A novel in situ gel base of deacetylase gellan gum for sustained ophthalmic drug delivery of ketotifen: in vitro and in vivo evaluation. Drug Des Dev Ther. 2015;9:3943-9. doi: 10.2147/DDDT.S87368, PMID 26251573.

35. Bhalerao H, Koteshwara KB, Chandran S. Brinzolamide dimethyl sulfoxide in situ gelling ophthalmic solution: formulation optimisation and in vitro and in vivo Evaluation. AAPS PharmSciTech. 2020;21(2):1-1569. doi: 10.1208/s12249-019-1555-0, PMID 31950311.

36. Yadav M, Guzman-Aranguez A, Perez de Lara MJ, Singh M, Singh J, Kaur IP. Bimatoprost loaded nanovesicular long-acting subconjunctival in-situ gelling implant: in vitro and in vivo evaluation. Mater Sci Eng C Mater Biol Appl. 2019;103;109730:109730. doi: 10.1016/j.msec.2019.05.015.

37. Ameeduzzafar, Imam SS, Bukhari SNA, Ali AAmeeduzzafar, Imam SS, Bukhari SNA, Ali A. Preparation and evaluation of novel chitosan: gelrite ocular system containing besifloxacin for topical treatment of bacterial conjunctivitis: scintigraphy, ocular irritation and retention assessment. Artificial Cells, Nanomed Biotechnol. 2018;46(5):959-67. doi: 10.1080/21691401.2017.1349779.

38. Kouchak M, Mahmoodzadeh M, Farrahi F. Designing of a pHtriggered carbopol囚/HPMC in situ gel for ocular delivery of dorzolamide $\mathrm{HCl}$ : in vitro, in vivo, and eex vvivo evaluation. AAPS PharmSciTech. 2019;20(5):1-8210. doi: 10.1208/s12249-019-1431-y, PMID 31161269.

39. Makwana SB, Patel VA, Parmar SJ. Development and characterization of in-situ gel for ophthalmic formulation 
containing ciprofloxacin hydrochloride. Results Pharma Sci. 2016;6:1-6. doi: 10.1016/j.rinphs.2015.06.001, PMID 26949596.

40. Okur NU, Yozgatli V, Okur ME. In vitro-in vivo evaluation of tetrahydrozoline-loaded ocular in situ gels on rabbits for allergic conjunctivitis management. Drug Dev Res. 2020 April;81(6):1-12716-27. doi: 10.1002/ddr.21677, PMID 32359095.

41. Morsi N, Ibrahim M, Refai H, El Sorogy H. Nanoemulsion-based electrolyte triggered in situ gel for ocular delivery of acetazolamide. Eur J Pharm Sci. 2017;104:302-14. doi: 10.1016/j.ejps.2017.04.013, PMID 28433750.

42. Patel N, Nakrani H, Raval M, Sheth N. Development of loteprednol etabonate-loaded cationic nanoemulsified in-situ ophthalmic gel for sustained delivery and enhanced ocular bioavailability. Drug Delivery. 2016;23(9):3712-23. doi: 10.1080/10717544.2016.1223225, PMID 27689408

43. Ibrahim MM, Abd-Elgawad AE, Soliman OA, Jablonski MM Nanoparticle-based topical ophthalmic formulations for sustained celecoxib release. J Pharm Sci. 2013;102(3):1036-53. doi: 10.1002/jps.23417, PMID 23293035.

44. Lim LT, Ah-Kee EY, Collins CE. Common eye drops and their implications for $\mathrm{pH}$ measurements in the management of chemical eye injuries. Int J Ophthalmol. 2014;7(6):1067-8. doi: 10.3980/j.issn.2222-3959.2014.06.29, PMID 25540767.
45. Baranowski P, Karolewicz B, Gajda M, Pluta J. Ophthalmic drug dosage forms: characterisation and research methods. Sci World J. 2014;2014:861904. doi: 10.1155/2014/861904. PMID 24772038.

46. Ustünda g-Okur N, Gokce EH, Bozbiyik DI, Egrilmez S, Ozer O, Ertan G. Preparation and in vitro-in vivo evaluation of ofloxacin loaded ophthalmic Nano structured lipid carriers modified with chitosan oligosaccharide lactate for the treatment of bacterial keratitis. Eur J Pharm Sci. 2014;63:204-15.

47. Pawar P, Kashyap H, Malhotra S, Sindhu R. Hp- $\beta-C D-$ voriconazole in situ gelling system for ocular drug delivery: in vitro, stability, and antifungal activities assessment. BiomMed Res Int. 2013;2013:341218:341218. doi $10.1155 / 2013 / 341218$.

48. Kurniawansyah IS, Rusdiana T, Wahab HA, Subarnas A. In situ ophthalmic gel with ion activated system. Int J Appl Pharm. 2019;11:15-8.

49. Majeed A, Khan NA. Ocular in situ gel: an overview. J Drug Delivery Ther 2019;9(1):337-47. doi: 10.22270/jddt.v9i1.2231.

50. Bhoyar BS, Agnihotrh VV, Bodhankar MM. A noval thermoreversible phase transition system with flux enhancers for ophthalmic application. Int J Pharm Pharm Sci. 2011;3:367-70. 